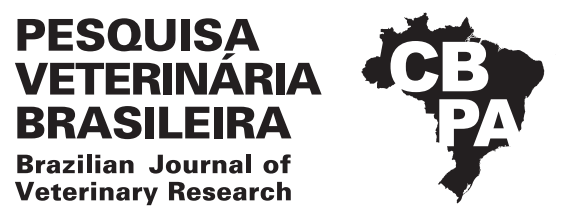

Pesq. Vet. Bras. 39(10):837-842, October 2019 DOI: 10.1590/1678-6160-PVB-6314

Original Article

Animal Morphophysiology

ISSN 0100-736X (Print)

ISSN 1678-5150 (Online)

\title{
Behaviour of diferent types of chitosan membranes implanted in horses ${ }^{1}$
}

\author{
Vinícius M. Rollim², Gustavo M. Reginato², Letícia M. Fernandes ${ }^{2}$, \\ Julia A. Arantes ${ }^{2}$, Eliana C.S. Rigo ${ }^{3}$, Luci C.O. Vercik ${ }^{3}$, Silvio H. Freitas ${ }^{2}$ \\ and Renata G.S. Dória ${ }^{2 *}$
}

\begin{abstract}
Rollim V.M., Reginato G.M., Fernandes L.M., Arantes J.A., Rigo E.C.S., Vercik L.C.O., Freitas S.H \& Dória R.G.S. 2019. Behaviour of diferent types of chitosan membranes implanted in horses. Pesquisa Veterinária Brasileira 39(10):837-842. Departamento de Medicina Veterinária, Faculdade de Zootecnia e Engenharia de Alimentos, Universidade de São Paulo, Campus Fernando Costa, R. Duque de Caxias 225, Jardim Elite, Pirassununga, SP 13635-900, Brazil. E-mail: redoria@usp.br

Chitosan has been successfully used as a biomaterial with several purposes in many species. In this study, chitosan membranes were produced with six different types of materials, and their behavior were evaluated upon implantation in the subcutaneous tissue of the flank of twelve healthy horses. We assessed chitosan membranes obtained from commercial chitosan, impregnated or not with silver nanoparticles, sterilized with ethylene oxide (CCEO, $n=3$; CCSNEO, $n=3$ ) or by ultraviolet radiation (CCUR, $n=3$; CCSNUR, $n=3$ ), and chitosan membranes obtained from squid gladius, sterilized with ethylene oxide (SCEO, $n=6$ ) or by ultraviolet radiation (SCUR, $\mathrm{n}=6$ ). The same animals were randomly used in two experimental groups, with a minimum interval of 60 days between procedures, respecting the fact of only one flank side, left or right, be under evaluation by experimental period. After preparation of the membranes and implantation in the flank subcutaneous tissue of the horses, macroscopic and ultrasonographic evaluations of the implant regions were performed, as well as physical examination, blood count and fibrinogen measurement. No clinical or laboratory abnormalities were observed. All animals that received commercial chitosan membranes, regardless of the preparation technique, showed rejection to the biomaterials, considering that $100 \%$ of the surgical wounds presented dehiscence of suture and expulsion of the implants. The animals that received squid gladius chitosan membranes showed success in the treatment, with healing by primary intention of the surgical wound. We conclude that squid gladius chitosan membranes are biocompatible and biodegradable when implanted in the subcutaneous tissue of the flank of healthy horses.
\end{abstract}

INDEX TERMS: Chitosan membranes, horses, implant, biomaterial, wound healing.

RESUMO.- [Comportamento de diferentes tipos de membranas de quitosana implantadas em equinos.] A quitosana tem sido utilizada, com sucesso, como biomaterial para diversas espécies e finalidades. Neste estudo foi avaliada

\footnotetext{
${ }^{1}$ Received on February 22, 2019.

Accepted for publication on May 28, 2019.

${ }^{2}$ Departamento de Medicina Veterinária (ZMV), Faculdade de Zootecnia e Engenharia de Alimentos, Universidade de São Paulo (USP), Campus Fernando Costa, R. Duque de Caxias 225, Jardim Elite, Pirassununga, SP 13635-900, Brazil. *Corresponding author: redoria@usp.br

${ }^{3}$ Departamento de Ciência Básicas (ZAB), Faculdade de Zootecnia e Engenharia de Alimentos, Universidade de São Paulo (USP) Campus Fernando Costa, R. Duque de Caxias 225, Jardim Elite, Pirassununga, SP 13635-900.
}

a confecção de membranas de quitosana, produzidas a partir de seis tipos de materiais diferentes e foi estudado seu comportamento quando implantadas no tecido subcutâneo do flanco de doze equinos sadios. Foram avaliadas membranas de quitosana obtidas de quitosana comercial, impregnadas ou não com nanopartículas de prata, esterilizadas com óxido de etileno (QCOE, $n=3$; QCNPOE, $n=3$ ) ou por radiação ultravioleta (QCRU, $n=3$; QCNPRU, $n=3$ ) e membranas de quitosana obtidas do gládio de lula, esterilizadas com óxido de etileno (GLOE, $n=6$ ) ou por radiação ultravioleta (GLRU, $n=6$ ). Os mesmos animais foram utilizados em dois grupos experimentais, de forma aleatória, com um intervalo mínimo de sessenta dias entre os procedimentos, respeitando-se o fato de apenas um lado 
do flanco, esquerdo ou direito, estar em avaliação por período experimental. Após preparo das membranas e implantação no tecido subcutâneo do flanco dos equinos, foram realizadas avaliações macroscópicas e ultrassonográficas das regiões de implante, além de exames físicos, hemogramas e fibrinogênio. Não foram observadas alterações clínicas e laboratoriais. Todos os animais que receberam membranas de quitosana comercial, independente da técnica de preparo, demonstraram rejeição dos biomateriais, uma vez que $100 \%$ das feridas cirúrgicas apresentaram deiscência da sutura e expulsão dos implantes. Os animais que receberam as membranas de quitosana de gladio de lula demonstraram sucesso no tratamento, com cicatrização das feridas cirúrgicas por primeira intenção. Conclui-se que membranas de quitosana de gládio de lula são biocompatíveis e biodegradáveis, quando implantadas no tecido subcutâneo do flanco de equinos sadios.

TERMOS DE INDEXAÇÃO: Membranas de quitosana, equinos, implante, biomaterial, cicatrização feridas, quitosana.

\section{INTRODUCTION}

Biomaterials of biological or synthetic nature can be widely used in the medical field as long as they are biocompatible, i.e., non-toxic, non-carcinogenic and non-antigenic, and do not stimulate inflammatory processes or favor infections (Alexander 1987, Iamaguti et al. 1995, Melo et al. 1998, Akamoto \& Trento 2002, Alievi et al. 2007, Turrer \& Ferreira 2008, Raposo-do-Amaral et al. 2010, Kuhl et al. 2017).

Chitosan, a chitin-derived polysaccharide, is the major component of the exoskeleton of crustaceans, mollusks and insects and of the cell wall of fungi and yeast. It has been used as biomaterial because of its numerous properties, such as biocompatibility and bioadhesiveness and action in the opening of epithelial tight junctions (Kumar 2000, 2004, Berger et al. 2004). Chitosan presents antimicrobial action, homeostatic activity, ability to activate macrophages, stimulate cell migration and proliferation, promote granulation tissue formation, and guide the reorganization of cellular histoarchitecture in wounds (Muzzarelli 2009, Kuhl et al. 2017). One of the most promising characteristics of chitosan for use as biomaterial is its excellent ability to be processed into porous structures, such as membranes, for use in cell transplantation, dressings and drug delivery (Denkbas \& Ottenbrite 2006).

The use of chitosan for wound healing as dressings developed in the form of sponges and porous membranes has been proven quite effective (Brown et al. 2009). In animal model experiments, chitosan has been shown to have a positive influence on all stages of tissue healing (Alemdaroğlu et al. 2006, Muzzarelli 2009). In horses, incisional infection is a concern in the postoperative period, as it delays surgical wound healing, resulting in increased postoperative care and convalescence, as well as in the need for surgical reintervention, as in cases of incisional hernias (Freeman 2018). In this interval, it is advantageous apply measures that reduce suppuration of the surgical wound in horses, such as the use of chitosan membranes, impregnated or not with antimicrobials, implanted in the subcutaneous tissue, in order to favor healing of the contact tissues such as muscles and skin.

One of the drawbacks of using implants in horses, whether of animal or synthetic origin, is the tissue reaction, or even rejection, that this species presents against tissues considered foreign to the body (Whitfield-Cargile et al. 2011). To date, no studies have been found in the literature addressing chitosan implantation in equine surgical wounds. Thus, this study aimed to develop different protocols for chitosan membrane production and evaluate their behavior when implanted in the subcutaneous flank tissue of healthy horses.

\section{MATERIALS AND METHODS}

This study was approved by the Research Ethics Committee of the aforementioned Institution under protocol no. 9840070118

Preparation of commercial chitosan membranes. Chitosan membranes were prepared using the casting technique. A $2 \%(\mathrm{w} / \mathrm{v})$ commercial chitosan solution (Sigma-Aldrich ${ }^{\circledR}$, low molecular weight) solubilized in $1 \%$ acetic acid solution (v/v) was prepared. After that, $25 \mathrm{~mL}$ of the solution were poured in a $90 \times 15 \mathrm{~mm}$ Petri dish. The Petri dishes were then stored in a forced air circulation oven. (Rainbow ${ }^{\circledR}$ ) for $48 \mathrm{~h}$

Preparation of commercial chitosan membranes impregnated with silver nanoparticles. The silver nanoparticles (AgNPs) were obtained using a commercial chitosan $6.92 \mathrm{mg} / \mathrm{mL}$ solution (SigmaAldrich $^{\circledR}$, low molecular weight) diluted in $1 \%$ acetic acid (v/v) and a silver nitrate solution (Tec-Lab ${ }^{\circledR}$ ) with concentration of $12 \mathrm{mM}$ diluted in distilled water. Both solutions were mixed and homogenized using a TE-0851 magnetic stirrer $\left(\mathrm{Tecnal}^{\circledR}\right)$ for approximately $15 \mathrm{~min}$, and then placed in a water bath at $90^{\circ} \mathrm{C}$ for $18 \mathrm{~h}$ (Wei \& Qian 2008).

The membranes were obtained from the AgNPs solution, with concentration adjustment up to $2 \%(\mathrm{~m} / \mathrm{v})$. Then $25 \mathrm{~mL}$ of the solution were poured in a $90 \times 15 \mathrm{~mm}$ Petri dish and the membranes were dried in a forced air circulation oven (Rainbow ${ }^{\circledR}$ ) for $48 \mathrm{~h}$.

Preparation of commercial chitosan membranes from squid gladius. The chitosan used in this stage was obtained from the extraction of $\beta$-chitin from pens of the squid species Doryteuthis spp. according to established methodology.

Squid pens provided by the Research Group in Biochemistry and Biomaterials of the "Instituto de Química de São Carlos" (IQSC-USP) were washed in running water to remove salts and organic material, oven dried at $40^{\circ} \mathrm{C}$, crushed, and separated using $0.250 \mathrm{~mm}$ sieve. Extraction of $\beta$-chitin from the squid pens and the preparation of chitosan were performed by deproteinization and $\mathrm{N}$-deacetylation, respectively, adapting a method described in the literature (Horn et al. 2009).

A $2 \%$ chitosan $(\mathrm{m} / \mathrm{v}) 1 \%$ acetic acid $(\mathrm{v} / \mathrm{v})$ solution was prepared. This mixture was kept under constant stirring at room temperature until complete solubilization. After that, the solution was poured into Petri dishes and dried in a forced air circulation oven (Rainbow ${ }^{\circledR}$ ) for $48 \mathrm{~h}$.

Chitosan membrane sterilization. After preparation, all membranes were reallocated in pre-perforated 90x15mm Petri dishes, packed in medical grade paper, and sterilized with ethylene oxide or by ultraviolet radiation.

In vivo test. Twelve grade horses with the following characteristics were used: average weight of $400 \pm 45 \mathrm{~kg}$, mean age of $6 \pm 2$ years, considered healthy after clinical and hematological evaluation, and fed $4 \mathrm{~kg}$ commercial horse feed (FZEA-USP, Pirassununga/SP), $2 \%$ body weight coast-cross grass hay, and mineral salt (FZEA-USP, Pirassununga/SP) and water ad libitum daily.

Chitosan membranes were implanted in the right and left lateral dorsal abdominal region (flank) of the horses. Three horses received commercial chitosan (CC) membranes sterilized with ethylene oxide (CCEO, $n=3$ ); three horses received CC membranes sterilized by ultraviolet radiation (CCUR, $n=3$ ); three horses received 
silver nanoparticle-impregnated CC membranes sterilized with ethylene oxide (CCSNEO, $n=3$ ); and three horses received silver nanoparticle-impregnated CC membranes sterilized by ultraviolet radiation (CCSNUR, $n=3$ ). Similarly, six horses received squid gladium chitosan (SC) membranes sterilized with ethylene oxide (SCEO, $n=6$ ) or by ultraviolet radiation (SCUR, $n=6$ ). The membranes were assessed for 15 days after the surgical procedure. The same animals were randomly used in two experimental groups, with a minimum interval of 60 days between procedures, respecting the fact of only one flank side, left or right, be under evaluation by experimental period.

During the surgical procedure, the animals were kept in the stable contained in squeeze chutes. After extensive hair trichotomy of the left or right flank regions, the animals were sedated with $10 \mu \mathrm{g} . \mathrm{kg}-1$ detomidine (Syntec, Santana do Parnaíba/SP), intravenous (IV), followed by infiltration local anesthesia with $2 \%$ lidocaine (Cristália, Itapira/SP) in inverted-L block. Antisepsis was performed using povidone-iodine and $70 \%$ alcohol. A $10 \mathrm{~cm}$ dorsoventral skin incision was made beginning $5 \mathrm{~cm}$ below the transverse processes of the lumbar vertebrae and $5 \mathrm{~cm}$ caudal to the last rib, followed by blunt subcutaneous tissue division and exposure of the external abdominal oblique muscle. The membranes were soaked in physiological solution in a stainless steel tank for $5 \mathrm{~min}$ and then placed on the subcutaneous tissue. Subsequently, the skin was sutured with simple separate needle stitches using \#1 surgical nylon thread (Sertix, Rio de Janeiro/RJ).

After the surgical procedure, antibiotic therapy with $20,000 \mathrm{IU} / \mathrm{kg}$ benzathine penicillin (Zoetis, São Paulo) was conducted every $48 \mathrm{~h}$, intramuscular (IM), for five days, and analgesia with $1.1 \mathrm{mg} / \mathrm{kg}$ flunixin meglumine (MSD, Cruzeiro/SP), IV, was performed every $24 \mathrm{~h}$ for three days. Surgical wounds were treated with topical povidone-iodine and Hipoglós ${ }^{\circledR}$ (Johnson \& Johnson, São Paulo/SP) was applied around them daily. The stiches were removed 10 days after the surgical procedure.

Physical assessment and evaluation of the implant region were performed prior to the surgical procedure (baseline) and after one (D1), two (D2), three (D3), four (D4), seven (D7), 10 (D10), and 15 (D15) days postoperatively.

The physical assessment consisted of measurement of heart rate by heart auscultation with stethoscope, respiratory rate by observation of rib cage motion, rectal temperature using a digital thermometer, intestinal motility by abdominal auscultation of the four abdominal quadrants, and mucosa staining and capillary filling time by inspection of the oral mucosa.

The implant region was evaluated for volume and temperature increase, leakage of suture exudate, and wound dehiscence. In addition, palpation around the skin suture was performed to identify tissue consistency, which was classified with fluctuation, normal, or with edema. The degree of pain observed on palpation was identified and classified as absent, mild, moderate, or severe.

Blood samples were collected from the jugular veins of the horses into tubes containing EDTA anticoagulant for blood count and fibrinogen measurement at baseline, D7 and D15.

Ultrasound assessment. An ultrasonographic evaluation (Mindray ${ }^{\circledR}$ M5VET) was performed in the implant region using a $10 \mathrm{MHz}$ microconvex probe immediately after the surgical procedure (baseline), and after seven (D7) and 15 (D15) days. In addition to the ultrasonographic aspects, the distance between the skin and the peritoneum was measured considering the presence of edema, clots, and exudate.
Histopathological evaluation. Fifteen days after the surgical procedure (D15), the animals were contained in squeeze chutes in the stable, and hair trichotomy and skin antisepsis were performed, followed by sedation with detomidine $(10 \mu \mathrm{g} . \mathrm{kg}-1)(\mathrm{IV})$ and infiltration local anesthesia with $2 \%$ lidocaine in inverted-L block of the implant region. $\mathrm{A} 1 \mathrm{~cm}^{3}$ fragment of subcutaneous tissue was collected, fixed in $10 \%$ buffered formalin, and stained with hematoxylin and eosin (HE) for histopathological evaluation. The skin wound was sutured with simple separate needle stitches using \#1 nylon surgical thread.

Statistical analysis. Parametric data obtained from the experimental procedure were analyzed using the Statistical Analysis System software, with prior verification of normality of residues by the Shapiro-Wilk test (PROC UNIVARIATE). Variables that did not meet the statistical assumptions underwent $\log (\mathrm{X}+1)$ transformation. Original or transformed data were submitted to analysis of variance (ANOVA) when this procedure was necessary. Repeated-measures ANOVA were conducted over time for the various sampling moments. The probabilities of interactions with time were determined by the Greenhouse-Geisse test using the REPEATED command generated by the MIXED procedure (SAS PROC MIXED). The Tukey's test was applied to find the means with significance level of 5\%.

Nonparametric data were evaluated descriptively regarding tissue reactions caused by the presence of the chitosan membrane in the subcutaneous space of the flank of the horses.

\section{RESULTS}

The membranes were successfully developed and sterilized according to the previously described techniques and implanted uneventfully on the flank of the horses. No changes were observed in the physical and laboratory evaluations during the experimental period, and the values found remained within the physiology for the species.

Regarding the macroscopic evaluations of the implant areas, $100 \%$ of the animals in the CCEO $(n=3)$, CCUR $(n=3)$, CCSNEO $(n=3)$ and CCSNUR $(n=3)$ groups presented circular volume increase at D1 and D2. As of D3, the following symptoms were observed: increase in temperature, presence of edema and serosanguinolent secretion, and moderate pain on palpation, with no difference between the experimental groups. All animals in these groups presented surgical wounds with suture dehiscence and implant expulsion (Fig.1) between D7 and D10. The expelled membranes underwent microbiological evaluation, and none of them showed growth of microorganisms in culture. At D0, the ultrasonographic examination showed the presence of the membranes in the subcutaneous tissue observed by formation of a hyperechoic line and clots. At D7, anechoic images were visualized between the skin and the muscles, characterizing fluid accumulation, and the membranes could be identified. All animals under study $(n=12)$ presented significant increase in the distance between the skin and the peritoneum, namely, D0 $=2.04 \pm 0.6$ and $D 7=4.5 \pm 1.2$, caused by skin edema and presence of free fluid in the subcutaneous tissue. At D15, no ultrasound evaluation was performed since the membranes had been expelled. The skin wounds healed with the application of daily topical dressings by secondary intention.

As for the animals in the SCEO $(n=6)$ and SCUR (n=6) groups, a slight increase in volume in the implant region was observed at D1, disappearing at D2. No temperature increase, exudate, or pain on palpation in the implant region were observed in any of the animals at the experimental times. Ultrasound 


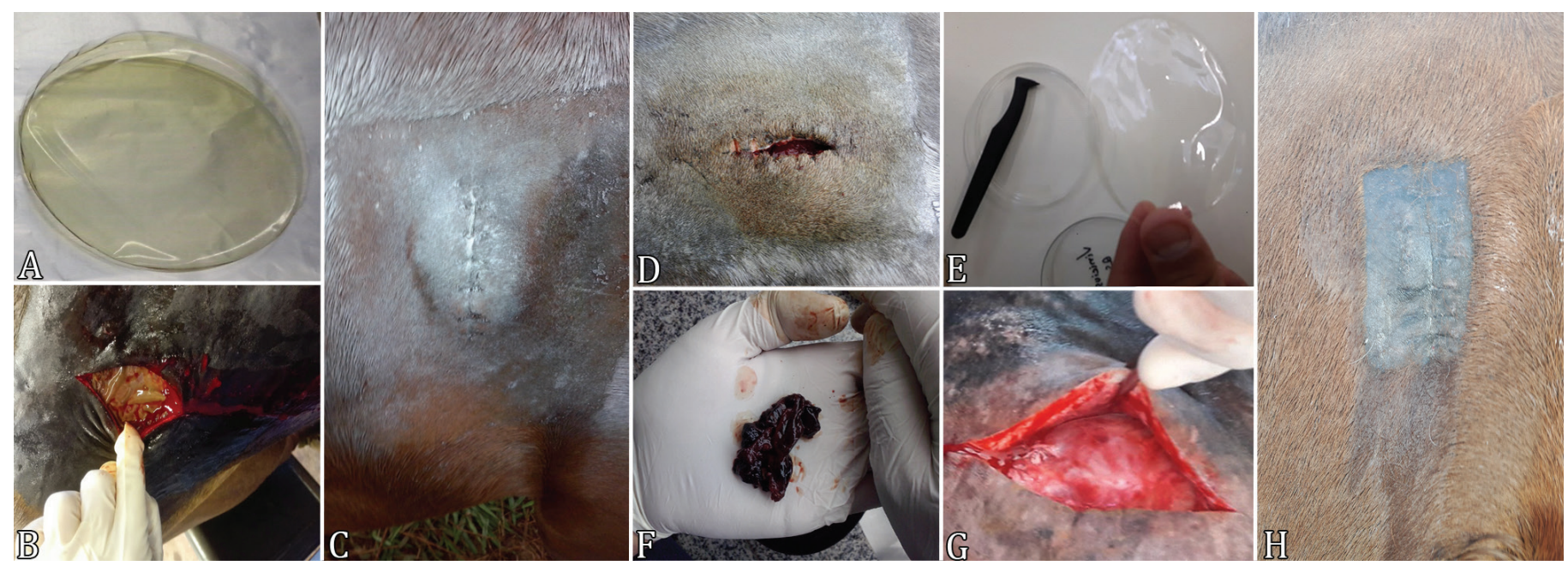

Fig.1. (A) Illustration of the commercial chitosan membrane (CC), (B) implantation of CC membrane in equine subcutaneous tissue, (C) subcutaneous swelling, (D) wound dehiscence in the CCEO group at D10, (E) CC membrane at D10, (F) squid gladius chitosan membrane (SC), (G) membrane implantation in equine subcutaneous tissue in the SCEO group, (H) surgical wound healing at D15 in the SCEO group.

assessment at D0 identified the membranes and clots in the subcutaneous tissue. At D7, it was possible to visualize the presence of the membrane in the subcutaneous tissue without fluid accumulation or tissue edema. Reduction in the distance between the skin and the peritoneum was observed $(\mathrm{n}=12)$ over the experimental period, namely, $\mathrm{D} 0=1.4 \pm 0.5$, $D 7=1.2 \pm 0.5$ and $D 15=0.9 \pm 0.2$, with no significant changes. At D15, it was not possible to identify the membranes in any animal in the experimental groups, with no changes in ultrasound image associated with skin, subcutaneous tissue and musculature. In $100 \%$ of the animals, healing of the skin sutures by first intention was observed, with removal of the stitches on D10 (Fig.1).

Histopathological examination was not performed in the animals in the CCEO, CCUR, CCSNEO and CCSNUR groups because the membranes, free in the subcutaneous tissue, were expelled through the open wounds after suture dehiscence. In the animals in the SCEO and SCUR groups, at D15, it was not possible to localize the membranes implanted in the subcutaneous tissue, and tissue fragments present between the skin and the muscles were collected. Histopathological evaluation revealed minimal to absent inflammatory reaction in the subcutaneous tissue, with small number of macrophages, and no other cell type characterizing changes in tissue was verified. No significant differences were observed between the samples.

\section{DISCUSSION}

This study demonstrated that squid gladium chitosan membranes present good acceptance in horses when implanted in subcutaneous tissue, regardless of the form of sterilization, either with ethylene oxide or by ultraviolet radiation.

In contrast, commercial chitosan membranes were not accepted in the subcutaneous tissue of the horses, resulting in rejection of the biomaterial, observed by the increase in temperature during the experimental period, formation of edema, and presence of pain on local palpation, as well as increased distance between the skin and the peritoneum at ultrasound assessment, and presence of exudate, wound dehiscence and implant expulsion.

Impregnation of chitosan membranes with silver nanoparticles aims at providing a greater antibacterial effect, because the silver ions ( $\mathrm{Ag}+$ ) bind to the membranes of the bacterial cells causing rupture of their walls, and are transported inside the cell, binding to DNA and RNA proteins, and interfering with energy production, enzyme function, and cell replication. In addition, by reducing the bacterial burden, silver reduces the inflammatory reaction by decreasing the activity of metalloproteinase, proinflammatory cytokines and cellular apoptosis (Leaper 2012, Shao et al. 2017). In this study, this alternative was not interesting in vivo, since $100 \%$ of the implanted animals rejected this biomaterial.

Although good in vitro results have been obtained in the manufacturing of commercial chitosan membranes impregnated or not with silver nanoparticles, when tested in vivo in the subcutaneous tissue of horses, they presented characteristic behavior, causing foreign body inflammatory reaction (Anderson et al. 2008) and rejection. In addition, the form of sterilization, with ethylene oxide or by ultraviolet radiation, was not responsible for the reaction to the implanted material, considering that all animals that received commercial chitosan implants showed rejection. Moreover, the expelled membranes tested negative in microbiological culture.

Therefore, a difference was observed regarding the type of chitosan with respect to the in vivo acceptance of the membranes when implanted in the subcutaneous tissue of horses. This finding was possibly associated with the difference in physical structure observed between them. Commercial chitosan is derived from $\alpha$-chitin, found in rigid structures such as arthropod cuticles, and in these cases, a strong association with proteins and/or inorganic materials occurs. Thus, there is difficulty in standardizing the characteristics of chitin in commercial chitosan in relation to the purity and quality of chitosan, even when using the same raw material and manufacturer. Moreover, $\alpha$-chitin, in addition to being the most abundant form, is considered to be more stable, since it corresponds to a dense packing of polymeric chains, 
which favors the existence of numerous inter- and intra-chain hydrogen bonds. In contrast, $\beta$-chitin occurs in flexible structures, although also resistant, being the main component of squid pens. In the case of $\beta$-chitin, strands belonging to different lamellae are arranged in parallel, which hinders the establishment of hydrogen bonds involving adjacent lamellae chains and results in a less packaged material. This morphology presents relatively weak intermolecular forces, facilitating solubility in various solvents, as well as greater swelling and higher chemical reactivity (Kurita et al. 1993, Chandumpai et al. 2004, Jang et al. 2004, Campana-Filho et al. 2007). It is thus hypothesized that these differences in characteristics between $\alpha$-chitin and $\beta$-chitin may have favored the non-recognition of the squid gladius implant as a foreign body by the horses of this study.

In vitro studies present numerous favorable characteristics regarding the use of chitosan in vivo, especially as an aid to wound healing (Berger et al. 2004, Alemdaroğlu et al. 2006, Campos et al. 2006, Azevedo et al. 2007, Brown et al. 2009, Muzzarelli 2009, Ganesh et al. 2016). In horses, there are studies that show positive results with the use of chitosan membranes on skin wounds (Martins et al. 2013). In contrast, no studies evaluating chitosan membranes when implanted in the subcutaneous tissue of horses were found in the literature. Kuhl et al. (2017) demonstrated, in rabbits, the non-integration of chitosan implants in bone failures. Shao et al. (2017) revealed an inflammatory reaction after subcutaneous implantation of chitosan membranes in rabbits, and reported the intact permanence of these membranes after 12 weeks of implantation. All of these studies were conducted with commercial chitosan.

The present study demonstrated that squid gladius chitosan membranes are biocompatible and biodegradable, and are metabolized by enzymes such as lysozyme (Muzzarelli 1997) when implanted in horses, considering that the membranes could not be localized in the subcutaneous tissue 15 days after the surgical procedure. Histopathological evaluation confirmed this finding, and showed no material suggestive of the presence of the membrane, as well as no cellularity that characterized foreign body inflammatory reaction, suggesting acceptance of the biomaterial.

Further studies addressing the use of squid gladius chitosan membranes implanted in tissues should be conducted in order to evaluate their practical applications in equine medicine, especially in assistance with incisional infections.

\section{CONCLUSION}

We conclude that squid gladium chitosan membranes are well accepted when implanted in the subcutaneous tissue of horses, being biocompatible and biodegradable, and suggest that this acceptance is due to the fact that this is a $\beta$-chitin material. Commercial chitosan membranes implanted in the subcutaneous tissue of horses result in rejection of the material.

\footnotetext{
Acknowledgements. - The authors are grateful to the "Fundação de Amparo à Pesquisa do Estado de São Paulo" (FAPESP) for the undergraduate research scholarship provided and to "Conselho Nacional de Desenvolvimento Científico e Tecnológico" (CNPq) for supporting this study.
}

Conflict of interest statement.- The authors declare having no conflicts of interest.

\section{REFERENCES}

Akamoto T. \& Trento C.L. 2002. Implante homógeno de matriz dentinária desmineralizada conservada em glicerina a 98\% em alvéolo dental: estudo microscópio em ratos. Revta Bras. Ciênc. Saúde 5:33-41.

Alemdaroğlu C., Değim Z., Celebi N., Zor F., Oztürk S. \& Erdoğan D. 2006. An investigation on burn wound healing in rats with chitosan gel formulation containing epidermal growth factor. Burns 32(3):319-327. <http://dx.doi. org/10.1016/j.burns.2005.10.015> <PMid:16527411>

Alexander J.W. 1987. Bone grafting. Vet. Clin. N. Am., Small Anim. Pract. 17(4):811-819.

Alievi M.M., Schossler J.E.W., Guimarães L.D., Oliveira A.N.C., Traeslel C.K. \& Ferreira P.A. 2007. Implante ósseo cortical alógeno conservado em mel na reconstrução de falha óssea diafisária em fêmur de cães: avaliação clínica e radiográfica. Ciência Rural 37(2):450-457.<http://dx.doi.org/10.1590/ S0103-84782007000200024>

Anderson J.M., Rodriguez A. \& Chang D.T. 2008. Foreign body reaction to biomaterials. Semin. Immunol. 20(2):86-100.<http://dx.doi.org/10.1016/j. smim.2007.11.004><PMid:18162407>

Azevedo V.V.C., Chaves S.A., Bezerra D.C., Lia Fook M.V. \& Costa A.C.F.M 2007. Quitina e Quitosana: aplicações como biomateriais. Revta Eletrôn. Materiais Processos 2(3):27-34.

Berger J., Reist M., Mayer J.M., Felt O., Peppas N.A. \& Gurny R. 2004. Structure and interactions in convalently and ionically crosslinked chitosan hydrogels for biomedical apllications. Eur. J. Pharm. Biopharm. 57(1):19-34. <http:// dx.doi.org/10.1016/S0939-6411(03)00161-9><PMid:14729078>

Brown M.A., Daya M.R. \& Worley J.A. 2009. Experience with chitosan dressings in a civilian EMS system. J. Emerg. Med. 37(1):1-7. <http://dx.doi. org/10.1016/j.jemermed.2007.05.043><PMid:18024069>

Campana-Filho S.P., Britto D., Curti E., Abreu F.R., Cardoso M.B., Battisti M.V., Sim P.C., Goy R.C., Signini R. \& Lavall R.L. 2007. Extração, estruturas e propriedades de $\alpha$-quitina e $\beta$-quitina. Quím. Nova 30(3):644-650.<http:// dx.doi.org/10.1590/S0100-40422007000300026>

Campos M.G.N., Santos Júnior A.R. \& Mei L.H.I. 2006. Evaluation of in vitro cytotocoxicity of chitosan membranes for wound dressing. Anais IV Congresso Latino Americano de Órgãos Artificiais e Biomateriais, Caxambú, MG.

Chandumpai A., Singhpibulporn N., Faroongsarng D. \& Sornprasit P. 2004. Preparation and physico-chemical characterization of chitin and chitosan from the pens of the squid species, Loligo lessoniana and Loligo formosana. Carbohydr. Polym. 58(4):467-474. <http://dx.doi.org/10.1016/j. carbpol.2004.08.015>

Denkbas E.B. \& Ottenbrite R.M. 2006. Perspectives on: Chitosan drug delivery systems based on their geometries. J Bioact Compat Pol. 21(4):351-368 <http://dx.doi.org/10.1177/0883911506066930>

Freeman D.E. 2018. Fifty years of colic surgery. Equine Vet. J. 50(4):423-435. <http://dx.doi.org/10.1111/evj.12817> <PMid:29405434>

Ganesh M., Aziz A.S., Ubaidulla U., Hemalatha P., Saravanakumar A., Ravikumar R., Peng M.M., Choi E.Y. \& Jang H.T. 2016. Sulfanilamide and silver nanoparticles-loaded polyvinyl alcohol-chitosan composite electrospun nanofibers: Synthesis and evaluation on synergism in wound healing. J. Ind Eng. Chem. 39:127-135. <http://dx.doi.org/10.1016/j.jiec.2016.05.021>

Horn M.M., Martins V.C.A. \& Plepis A.M.G. 2009. Interaction of anionic collagen with chitosan. Effect on thermal and morphological characteristics. Carbohydr Polym. 77(2):239-243. <http://dx.doi.org/10.1016/j.carbpol.2008.12.039>

Iamaguti P., Ineo A.P., Del Carlo R.J., Muniz L.M., Mamprim M.J. \& Dal Pai V. 1995. Uso de auto-enxerto ósseo esponjoso na reparação do rádio. Estudo experimental em coelhos. Vet. Zootec. 7:49-61.

Jang M., Kong B., Jeong Y., Lee C.H. \& Nah J. 2004. Physicochemical characterization of $\alpha$-chitin, $\beta$-chitin, and $\gamma$-chitin separated from natural resources. J. Polym. Sci. A, Polym. Chem. 42(14):3423-3432. <http://dx.doi org/10.1002/pola.20176> 
Kuhl G.S., Rigo E.C.S., Vercik L.C.O., Dória R.G.S., Santos M.D., Hage M.C.F.N.S., Ambrósio C.E. \& Freitas S.H. 2017. Aspecto morfológico da interface entre o compósito, constituído de quitosana e polimetilmetacrilato, e a falha óssea de tíbia de coelhos. Pesq. Vet. Bras. 37(12):1491-1498. <http:// dx.doi.org/10.1590/s0100-736x2017001200021>

Kumar M.N.V.R. 2000. A review of chitin and chitosan applications. React. Funct. Polym. 46(1):1-27. <http://dx.doi.org/10.1016/S1381-5148(00)00038-9>

Kumar M.N.V.R., Muzzarelli R.A.A., Muzzarelli C., Sashiwa H. \& Domb A.J. 2004. Chitosan chemistry and pharmaceutical perspectives. Chem. Rev. 104(12):6014-6084. <http://dx.doi.org/10.1021/cr030441b> $<$ PMid:15584695>

Kurita T., Tomita K., Tada T., Ishii S., Nishimura S. \& Shimoda K. 1993. Squid chitin as a potential alternative chitin source: deacetylation behavior and characteristic properties. J. Polym. Sci. A, Polym. Chem. 32(2):485-491. <http://dx.doi.org/10.1002/pola.1993.080310220>

Leaper D. 2012. Appropriate use of silver dressings in wounds. Int. Wound J. 9(5):461-464. <http://dx.doi.org/10.1111/j.1742-481X.2012.01091. $\mathrm{x}><$ PMid:22994382>

Martins E.A.N., Invernizzi M.S., Campos M.G.N., Teodoro P.A., Contieri M.B. \& Silva L.C.L.C. 2013. Emprego de membrana de quitosana em feridas cutâneas induzidas experimentalmente em equinos. Ciência Rural 43(10):1824-1830. <http://dx.doi.org/10.1590/S0103-84782013001000015>

Melo E.G., Rezende C.M.F., Borges A.P.B. \& Nóbrega Neto P.I. 1998. Aloenxerto ósseo cortical: avaliação do seu emprego em tíbia de cão. Arq. Bras. Med. Vet. Zootec. 50(4):385-394.
Muzzarelli R.A.A. 1997. Human enzymatic activities related to the therapeutic administration of chitin derivatives. Cell. Mol. Life Sci. 53(2):131-140. <http://dx.doi.org/10.1007/PL00000584><PMid:9118001>

Muzzarelli R.A.A. 2009. Chitins and chitosans for the repair of wouded skin, nerve, cartilage and bone. Carbohydr. Polym. 76(2):167-182. <http:// dx.doi.org/10.1016/j.carbpol.2008.11.002>

Raposo-do-Amaral C.A.A., Raposo-do-Amaral C.E., Roland F.G., Silva J.V.L., Paschoal G.H.L., Silva A.M., Carone D.R., Menon D.N., Silva M.P.A., Bento D.F., Almeida F.L. \& Buzzo C.L. 2010. Implantes pré-fabricados customizados nas grandes perdas ósseas do esqueleto craniofacial. Revta Bras. Cir. Craniomaxilofacial 13(3):175-179.

Shao J., Yu N., Kolwijck E., Wang B., Tan K.W., Jansen J.A., Walboomers X.F. \& Yang F. 2017. Biological evaluation of silver nanoparticles incorporated into chitosan-based membranes. Nanomedicine, London, 12(22):2771-2785. <http://dx.doi.org/10.2217/nnm-2017-0172> $<$ PMid:28967828>

Turrer C.L. \& Ferreira F.P.M. 2008. Biomateriais em cirurgia craniomaxilofacial: princípios básicos e aplicações: revisão de literatura. Revta Bras. Cir. Plást. 23(3):234-239.

Wei D. \& Qian W. 2008. Facile synthesis of Ag and Au nanoparticles utilizing chitosan as a mediator agent. Colloids and Surfaces B: Biointerfaces. 62(1):136-142. <http://dx.doi.org/10.1016/j.colsurfb.2007.09.030> <PMid:17983734>

Whitfield-Cargile C.M., Rakestraw P.C., Hardy J., Cohen N.D. \& Davis B.E. 2011. Comparison of primary closure of incisional hernias in horses with and without the use of prosthetic mesh support. Equine Vet. J.39(Suppl.):69-75. <http://dx.doi.org/10.1111/j.2042-3306.2011.00377.x><PMid:21790757> 